Article

\title{
Conservation and Utilization of Livestock Genetic Diversity in the United States of America through Gene Banking
}

\author{
Harvey D. Blackburn * (1), Carrie S. Wilson and Bethany Krehbiel \\ National Animal Germplasm Program, Center for Agricultural Resources Research, United States Department of \\ Agriculture, Fort Collins, CO 80521, USA; carrie.wilson@usda.gov (C.S.W.); bethany.Krehbiel@usda.gov (B.K.) \\ * Correspondence: harvey.blackburn@ars.usda.gov
}

Received: 19 November 2019; Accepted: 15 December 2019; Published: 17 December 2019

\begin{abstract}
A germplasm collection curated by the United States Department of Agriculture (USDA), Agricultural Research Service (ARS), National Animal Germplasm Program contains of over one million samples from over 55,000 animals, representing 165 livestock and poultry breeds. The collection was developed to provide genetic conservation and security for the U.S. livestock sector. Samples in the collection span 60 years, suggesting a wide range of genetic diversity and genetic change is represented for rare and major breeds. Classifying breeds into four groups based upon registration or census estimates of population size of $<1000,<5000,<20,000$, and $>20,000$ indicated that $50 \%$ of the collection is comprised of rare breeds in the $<1000$ category. As anticipated, collections for breeds in the $<20,000$ and $>20,000$ are more complete ( $86 \%$ and $98 \%$, respectively) based upon an index combining the number of germplasm samples and the number of animals. For the rarest breeds $(<1000)$, collection completeness was $45 \%$. Samples from over 6000 animals in the collection have been used for adding diversity to breeds, genomic evaluation, reconstituting populations, or various research projects. Several aspects of collecting germplasm samples from rare breeds are discussed. In addition, approaches that could be used to enhance the status of rare breeds via the repository use are presented. However, given the array of obstacles confronting rare breeds, the gene bank may be the most secure prospect for the long-term conservation of rare breed genetics.
\end{abstract}

Keywords: gene bank; biorepository; genetic diversity; livestock

\section{Introduction}

The task of conserving rare and/or minor breeds has been a global challenge for the past 20 to 30 years, as noted by the development of the World Watch List for Domestic Animal Diversity [1] and subsequent State of the World Reports [2,3]. Some successes to this end have been achieved, as evidenced by the increase in population size (or breed registration numbers) for some populations. Nonetheless, globally, improvement in genetic security has been marginal or rare for in situ populations [3]. In part, rare breeds are subjected to endangerment principally due to small population sizes which, in turn, amplify the effects of genetic drift and selection [4-6]. Compounding these biological aspects, there is an insufficient number of breeders, as well as a lack of breeder longevity and the organization $[7,8]$ needed for concerted action to improve rare breed competitiveness with numerically-larger breeds. Furthermore, as market structures become more complex and consolidated, market entry may become more difficult.

The above challenges can be viewed from the perspective of national agricultural policies that are focused upon promoting economic growth and food security. Norton [9] explains that at the producer level, agricultural policies should address three basic needs: incentives to produce (not to be confused 
with subsidized production), a secure resource base, and access to markets for outputs and inputs. The development of animal germplasm collections serves the basic purposes of securing a country's genetic resource base [10] and making those resources available to stakeholders.

In the United States, the USDA's National Animal Germplasm Program (NAGP) was initiated in 1999 to address the issue of conserving livestock, poultry, and aquatic genetic resources [11-13]. This study details elements of the progress to date and future activities that not only increase genetic security, but may also increase the utilization of genetic resources.

\section{Materials and Methods}

The effective gene banking of breeds requires genetic assessments of populations (within and among breeds), cryopreservation protocols for varying gametes and/or tissues, and a publicly-accessible database that provides a mechanism by which to monitor the inventory and inform stakeholders about which samples are maintained in the collection. Genetic assessments have largely been performed using either pedigree and/or genomic information. Pedigree evaluations (computation of coefficients of genetic relationships) are used with Ward's clustering technique, as demonstrated by Ouendeba, et al. [14].

Germplasm acquired for the collection is achieved through a variety of approaches, and is dependent upon industry infrastructure. For example, beef and dairy cattle germplasm is primarily cryopreserved at private sector studs throughout the nation, while boar germplasm is collected and shipped and then cryopreserved at the NAGP laboratory. In addition, other tissue types which may be useful in regenerating populations have been collected and cryopreserved (embryos, ovaries, and testes).

A comprehensive information system, i.e., Animal-GRIN [15], that is publicly accessible, has been developed in collaboration with the Brazilian and Canadian national genetic resource programs. In addition to monitoring samples in the collection, the database provides information on breeds and specific animals, including phenotypic, genotypic, management, and production system information. Animal pedigrees are also maintained, allowing the user to evaluate the genetic relationships among the collection animals within a breed.

\section{Results}

\subsection{Current Collection}

The USDA National Animal Germplasm Program germplasm and tissue collection is quite broad, consisting of 1070,258 samples from 55,094 animals that represent 40 species, 168 breeds, and 350 unique subpopulations. In 1999, the collection was initiated. Some of the samples in the collection were frozen in the 1950s, thereby enabling the collection to be used to evaluate the historical changes that have occurred [13] among various breeds. The following describes several of the unique attributes of the collection that exemplify the breadth of genetics acquired to date. In the late 1960s and 70s the U.S. beef industry imported new continental breeds of cattle (e.g., Simmental, Salers, Limousin). Samples from many of the original imported bulls reside in the collection. The same holds true for the three pig breeds imported from China in the late 1980s. As might be expected, the collection contains many historically-important animals, for example $>99 \%$ of Holstein AI sires born in 2010 can be traced to just two bulls, i.e., Chief and Elevation [16]; samples from both of these bulls are in the collection. The collection also contains multigenerational samples which make possible any variety of research projects possible where such a data structure is useful.

Sampling breeds is a continuous process, so changes in genetic variability over time can be captured [13]. For commercially-important breeds with aggressive selection programs, resampling needs to occur at approximately four- to five-generation intervals, where generation intervals range from one (poultry) to four (beef cattle) years. However, most rare breeds lack consistent and intensive 
selection pressure; therefore, their generation intervals tend to be longer, and any resampling of those breeds can occur at much longer intervals, e.g., 10 to 20 generations.

Table 1 lists the breeds represented in the collection. The breeds are partitioned into four categories, based upon annual registrations or census information: < 1000 animals, 1000 to 5000 animals, 5001 to 20,000 animals, and $>20,000$ animals. These categories deviate from previously-derived classifications. Breeds listed within the same category tend to have a similar set of issues in relation to their conservation and how the gene bank may be used. For example, breeds with less than 1000 head tend to have smaller numbers of breeders, small flock or herd sizes, a rapid turnover of breeders entering and exiting their production, disparate selection programs, less selection intensity, and are most vulnerable to genetic drift. The next largest category of breeds, i.e., having $<5000$ animals or registrations per year, contends with a similar set of challenges, but it does have more flexibility in terms of resolving the aforementioned challenges. The third and fourth groups, while numerically large and with the potential to overcome many of the biological and breeder issues, may still have genetic resource issues, for example, relatively small population sizes and the emergence of lethal mutations due to high relatedness [16,17]. However, these groups tend to have organizations and breeders that can leverage resources to address a broad array of problems.

Table 1. Categorization of mammalian breeds by species in the collection based upon annual registrations or census information.

\begin{tabular}{|c|c|c|c|c|c|}
\hline $\begin{array}{l}\text { Registration } \\
\text { /Census } \\
\text { Category } \\
\text { (Animals) }\end{array}$ & Beef Cattle & Dairy Cattle & Sheep & Goats & Pigs \\
\hline$<1000$ & $\begin{array}{c}\text { 23-Belgian Blue, Blonde } \\
\text { d' Aquitaine, Chianina, } \\
\text { Criollo, Devon, Florida } \\
\text { Cracker/Pineywoods, } \\
\text { Galloway, Marchigiana, } \\
\text { Masona, Murray Grey, } \\
\text { Normande, Parthenais, } \\
\text { Red Poll, Romagnola, } \\
\text { Romosinuano, Senepol, } \\
\text { South Devon, Tarentaise, } \\
\text { Tuli, White Park, Nelore, } \\
\text { Tabapua, Indu Brazil }\end{array}$ & $\begin{array}{l}\text { 7-Dutch Belted, } \\
\text { Herens, Kerry, } \\
\text { Meuse-Rhine-Yssel, } \\
\text { Milking Devon, } \\
\text { Norwegian Red, } \\
\text { Randall Lineback }\end{array}$ & $\begin{array}{c}\text { 24-Barbados Blackbelly, } \\
\text { Black Welsh Mountain, } \\
\text { Bluefaced Leicester, Border } \\
\text { Leicester, Cotswold, } \\
\text { Delaine Merino, } \\
\text { Finnsheep, Gulf Coast } \\
\text { Native, Hog Island, } \\
\text { Icelandic, Jacob, Karakul, } \\
\text { Leicester Longwool, } \\
\text { Lincoln, Merino, Navajo } \\
\text { Churro, North Country } \\
\text { Cheviot, Romadale, Santa } \\
\text { Cruz Island, Scottish } \\
\text { Blackface, Shetland, Soay, } \\
\text { Saint Croix, Texel }\end{array}$ & $\begin{array}{l}\text { 4-Kiko, Sable, } \\
\text { San Clemente, } \\
\text { Savanna }\end{array}$ & $\begin{array}{l}\text { 10-Fengjing, } \\
\text { Gloucestershire } \\
\text { Old Spot, } \\
\text { Guinea Hog, } \\
\text { Mangalitsa, } \\
\text { Meishan, } \\
\text { Minzu, } \\
\text { Mulefoot, } \\
\text { Ossabaw } \\
\text { Island, Red } \\
\text { Wattle, } \\
\text { Saddleback }\end{array}$ \\
\hline$<5,000$ & $\begin{array}{c}\text { 12-Belted Galloway, } \\
\text { Braunvieh, British White, } \\
\text { Highland, Piedmontese, } \\
\text { Pinzgauer, Texas } \\
\text { Longhorn, Wagyu, } \\
\text { Braford, Simbrah, Red } \\
\text { Brangus, Santa Gertrudis }\end{array}$ & $\begin{array}{l}\text { 4-Ayrshire, Dexter, } \\
\text { Guernsey, Milking } \\
\text { Shorthorn }\end{array}$ & $\begin{array}{l}\text { 6-Columbia, Corriedale, } \\
\text { Polypay, Romanov, } \\
\text { Shropshire, Targhee }\end{array}$ & $\begin{array}{l}\text { 6-Lamancha, } \\
\text { Myotonic, } \\
\text { Nigerian } \\
\text { Dwarf, } \\
\text { Oberhasli, } \\
\text { Saanen, } \\
\text { Togenburg }\end{array}$ & $\begin{array}{c}\text { 2-Tammworth, } \\
\text { Hereford }\end{array}$ \\
\hline$<20,000$ & $\begin{array}{c}\text { 6-Limousin, } \\
\text { Maine-Anjou, Salers, } \\
\text { Shorthorn, Beefmaster, } \\
\text { Brahman }\end{array}$ & 1-Brown Swiss & $\begin{array}{c}\text { 7-Dorper, Dorset, } \\
\text { Hampshire, Katahdin, } \\
\text { Southdown, Suffolk, } \\
\text { Rambouillet }\end{array}$ & $\begin{array}{l}\text { 2-Alpine, } \\
\text { Nubian }\end{array}$ & $\begin{array}{l}\text { 3-Chester } \\
\text { White, Pietrain, } \\
\text { Poland China }\end{array}$ \\
\hline$>20,000$ & $\begin{array}{l}\text { 7-Angus, Charolais, } \\
\text { Gelbvieh, Hereford, Red } \\
\text { Angus, Brangus, } \\
\text { Simmental }\end{array}$ & 2-Holstein, Jersey & 0 & $\begin{array}{c}\text { 3-Angora, } \\
\text { Boer, Spanish }\end{array}$ & $\begin{array}{l}\text { 6-Berkshire, } \\
\text { Duroc, } \\
\text { Hampshire, } \\
\text { Landrace, } \\
\text { Spotted, } \\
\text { Yorkshire }\end{array}$ \\
\hline
\end{tabular}

Table 2 summarizes several aspects of the mammalian collection status based upon the four population categories identified in Table 1. Stakeholders have used breeds in all census categories for multiple purposes including corrective mating, genomic evaluation, research purposes, rebuilding a breed by adding lost genetic diversity, and population reconstitution. Samples from over 6000 animals have exited the collection for the purposes listed, indicating that collection use has exceeded the overarching goal of genetic conservation for worst-case scenarios. 
Table 2. Summary of gene bank collection use, collection frequency, collection completeness, and other attributes of the collection of mammalian species.

\begin{tabular}{|c|c|c|c|c|c|}
\hline $\begin{array}{l}\text { Registration } \\
\text { /Census } \\
\text { Category } \\
\text { (Animals) }\end{array}$ & Collection Use & $\begin{array}{c}\text { Frequency of } \\
\text { Collection }\end{array}$ & $\begin{array}{c}\text { Average } \\
\text { Collection } \\
\text { Completeness } \\
\text { (Minimum } \\
\text { Target Goal *), \% }\end{array}$ & Collection Issues & $\begin{array}{c}\text { Special } \\
\text { Attributes }\end{array}$ \\
\hline$<1000$ & $C, G, E, R, B$ & $\begin{array}{l}\text { Gaps in time } \\
\text { between } \\
\text { collections }\end{array}$ & 45.3 & $\begin{array}{l}\text { Small population } \\
\text { sizes, geographic } \\
\text { separation of } \\
\text { breeders }\end{array}$ & $\begin{array}{l}\text { original } \\
\text { imports, small } \\
\text { farmer }\end{array}$ \\
\hline$<5000$ & $C, G, E, R, B$ & $\begin{array}{l}\text { Gaps in time } \\
\text { between } \\
\text { collections }\end{array}$ & 75.1 & $\begin{array}{l}\text { Small population } \\
\text { sizes, geographic } \\
\text { separation of } \\
\text { breeders }\end{array}$ & $\begin{array}{l}\text { original } \\
\text { imports, small } \\
\text { farmer }\end{array}$ \\
\hline$<20,000$ & $C, G, E, R, B$ & Continuous & 86.1 & $\begin{array}{l}\text { Short generation } \\
\text { intervals, fine scale } \\
\text { sampling possible }\end{array}$ & $\begin{array}{l}\text { Time span, } \\
\text { original } \\
\text { imports }\end{array}$ \\
\hline$>20,000$ & $C, G, E, R, B$ & Continuous & 97.7 & $\begin{array}{l}\text { Short generation } \\
\text { intervals, fine scale } \\
\text { sampling possible }\end{array}$ & $\begin{array}{l}\text { Time span, } \\
\text { original } \\
\text { imports }\end{array}$ \\
\hline
\end{tabular}

$\mathrm{C}=$ corrective mating; $\mathrm{G}=$ genomic evaluation; $\mathrm{E}=$ reconstituting breed, $\mathrm{R}=$ research projects, $\mathrm{B}=$ rebuilding breed by adding diversity or breed admixture. * Minimum target goal is an index, ranging from 0.0 to 1.0 , which combines germplasm quantity and minimum number of animals needed to reconstitute a breed to $150 \%$ with an effective population size of 50 .

Table 3 provides an overview of the collection's 21 chicken breeds. Seventy-one percent of the breeds have $<5000$ animals. In the U.S., these breeds are typically denoted as fancier, and are maintained by fewer than 10 breeders. Avian species represent a unique challenge, in that the male is homogametic and the egg is too large to be cryopreserved. As a result, a collection of only semen lacks the mitochondria DNA (as with mammals), but is also missing an entire chromosome. To broaden the captured poultry genome, ovaries and testes from chicks one to three days of age have been collected and cryopreserved. These tissue types can then be thawed and transplanted into recipient chicks as a means of rebuilding populations. Somatic cell tissues have been collected for future DNA analyses.

Table 3. Chicken breed collection summary, including quantity of samples, types of germplasm and tissue stored, and collection completeness.

\begin{tabular}{|c|c|c|c|c|c|c|c|c|}
\hline $\begin{array}{c}\text { Registration/Census } \\
\text { Category } \\
\text { (Animals) }\end{array}$ & Breed & $\begin{array}{l}\text { Animal } \\
\text { Number }\end{array}$ & $\begin{array}{c}\text { Units of } \\
\text { Germplasm }\end{array}$ & Semen & Ovaries & Testes & $\begin{array}{l}\text { Somatic } \\
\text { Cells }\end{array}$ & $\begin{array}{c}\text { Collection } \\
\text { Completeness } \\
(\%)\end{array}$ \\
\hline$<1000$ & Crevecoeur & 100 & 170 & & 52 & 48 & 70 & 100 \\
\hline$<1000$ & Aseel & 97 & 161 & & 56 & 41 & 64 & 100 \\
\hline$<1000$ & $\begin{array}{l}\text { Transylvania } \\
\text { Naked Neck }\end{array}$ & 2 & 46 & 46 & & & & 6 \\
\hline$<1000$ & Redcap & 4 & 8 & & 2 & 2 & 4 & 9 \\
\hline$<1000$ & Spanish & 7 & 8 & 8 & & & & 10 \\
\hline$<5000$ & Sumatra & 2 & 11 & 11 & & & & 4 \\
\hline$<5000$ & Buttercup & 84 & 140 & & 52 & 31 & 57 & 100 \\
\hline$<5000$ & Polish & 28 & 84 & & 15 & 13 & 56 & 64 \\
\hline$<5000$ & Java & 40 & 80 & & 20 & 20 & 40 & 92 \\
\hline$<5000$ & Jersey Giant & 40 & 77 & & 32 & 18 & 27 & 100 \\
\hline$<5000$ & Andalusian & 70 & 109 & & 46 & 24 & 39 & 100 \\
\hline$<5000$ & New Hampshire & 57 & 334 & 81 & 40 & 8 & 205 & 100 \\
\hline$<5000$ & Old English Game & 8 & 252 & 252 & & & & 31 \\
\hline$<5000$ & Phoenix & 85 & 191 & 27 & 45 & 38 & 81 & 100 \\
\hline$<5000$ & Buckeye & 74 & 118 & & 52 & 22 & 44 & 100 \\
\hline$<20,000$ & Fayoumi & 68 & 135 & 108 & 19 & 8 & & 100 \\
\hline$>20,000$ & Silkie & 3 & 37 & 37 & & & & 7 \\
\hline$>20,000$ & Leghorn & 4985 & 9415 & 4893 & 1959 & 1898 & 665 & 100 \\
\hline$>20,000$ & Cornish & 777 & 1099 & 322 & 583 & 194 & & 100 \\
\hline$>20,000$ & Rhode Island Red & 78 & 188 & 14 & 53 & 23 & 98 & 100 \\
\hline$>20,000$ & Plymouth Rock & 178 & 896 & 562 & 88 & 34 & 212 & 100 \\
\hline
\end{tabular}


The index for average collection completeness was derived and based upon the minimum number of germplasm samples needed to reconstitute a breed to 150\% with an effective population size of 50, as calculated by Food and Agriculture Organization (FAO) [18]. For easy comparison, the NAGP has developed an index combining animal number and germplasm quantity in the numerator and FAO target animal numbers and germplasm in the denominator. The average index value for each population group indicates that the collection is well established, in general, and especially for breeds within the three largest population categories. While the category for breeds with $<1000$ registrations per year had the lowest level of completeness, the index tends to be biased downward based upon the following. Across mammalian species, there are 18 to 20 breeds that were imported into the U.S. which have not become established and viable breeds in terms of population size and number of breeders raising them (e.g., Fengjing, Mangalitsa, Blonde D' Aquitaine, Herens, Meuse-Rhine-Yssel, and Shetland). While the genetic base is limited, they still add unique genetic resources to the collection. In addition, breeds with the smallest populations (e.g., San Clemente goats) will likely never have sufficient population sizes to enable unique germplasm to be collected to have sufficient genetic diversity for reconstitution. In such cases, the collection strategy is to collect groups of animals over long periods as a mechanism to capture genetic change as it occurs. Poultry collection completeness by averaging index values was $72 \%$ among all chicken breeds. Of breeds with $<5000$ birds, eight had a collection completeness of $100 \%$, and the remaining five had a collection completeness of $64 \%$ or less (Table 3).

Sufficiently securing genetic variability for breeds in larger population groups requires a more frequent collection strategy to keep pace with faster genetic changes in order to keep the collection refreshed and relevant for the breeds in these categories. The goal of such a strategy is to minimize the time needed to produce progeny relevant to current industry needs $[19,20]$. In addition, with their available infrastructure, large breed associations can utilize pedigree data for the analysis of collection gaps, as previously described.

Populations with $<1000$ represent a challenge in executing collection activities, principally due to a lack of infrastructure for germplasm collection (semen or embryos) and on-farm expertise of breeders. To date, we have used an array of approaches to accomplish collection goals. For example, collecting germplasm from animals at national shows, developing specific collection workshops where breeders may bring their animals to be collected, and targeting on-farm collections for individual breeders known to have important herds or flocks of a rare breed. More recently, with the development of techniques for cloning in mammals, collection activities will migrate, in part, to collecting ear notches harvested by breeders. We anticipate this activity to substantially broaden the diversity acquired for rare mammalian breeds. Chicken collection activities will likely shift to harvesting primordial germ cells in combination with using gene-edited birds in the reconstitution process.

\subsection{Analyses of Breed Diversity}

Effective population size $(\mathrm{Ne})$ is a basic statistic that can be useful in assessing the genetic variability of a breed. From several sources, indicative breed effective population sizes are summarized in Table 4. In general, Ne tends to be less than 100 animals, which has been suggested as a benchmark for assessing breed diversity, although FAO [18] has suggested 50 animals be used as a minimum goal. Further understanding the genetic diversity in the collection and how it might be used is an ongoing process as new information and techniques become available. A series of pedigree and genomic studies have been performed to assess various species and breeds among species [7,8,21-24]. In general, within-breed genetic analysis has tended to suggest a contraction of genetic diversity among most breeds in the collection. Figure 1 demonstrates how Ne has decreased over time for pig breeds based upon molecular data and the computation of linkage disequilibrium [24]. 


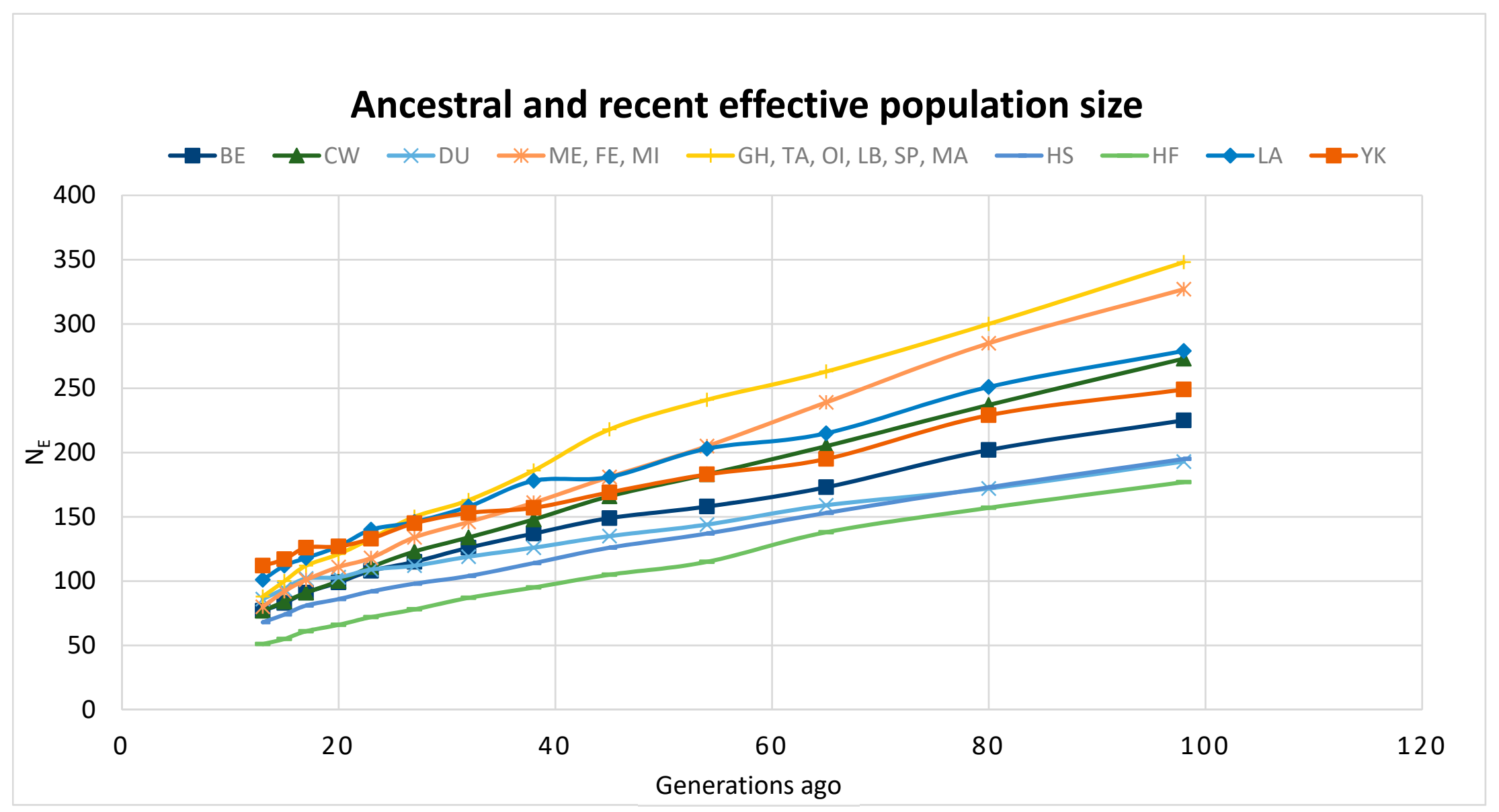

Figure 1. Change in effective population size of pig breeds in the gene bank across generations. $\mathrm{BE}=$ Berkshire; $\mathrm{CW}=\mathrm{Chester}$ White; $\mathrm{DU}=\mathrm{Duroc} ; \mathrm{ME}$, FE, MI = Meishan, Fengjing, Minzhu; GH, TA, OI, LB, SP, MA = Guinea Hog, Tamworth, Ossabaw Island, Large Black, Spotted, Mangalista; HS = Hampshire; $\mathrm{HF}=$ Hereford; LA = Landrace; YK = Yorkshire. From Faria, et al., 2019 [24]. 
Table 4. Indicative effective population sizes for mammalian species in the gene bank.

\begin{tabular}{|c|c|c|c|}
\hline Species & Breed & $\mathrm{Ne}$ & Method of Computation \\
\hline \multirow[t]{4}{*}{ Goats } & Angora & 121 & molecular \\
\hline & Boer & 59 & molecular \\
\hline & LaMancha & 41 & molecular \\
\hline & Spanish & 105 & molecular \\
\hline \multirow[t]{7}{*}{ Pigs } & Duroc & 86 & molecular \\
\hline & Berkshire & 77 & molecular \\
\hline & Chester White & 77 & molecular \\
\hline & Hampshire & 68 & molecular \\
\hline & Hereford & 51 & molecular \\
\hline & Landrace & 101 & molecular \\
\hline & Yorkshire & 112 & molecular \\
\hline \multirow[t]{8}{*}{ Cattle } & Brangus & 90 & pedigree * \\
\hline & Hereford & 85 & pedigree * \\
\hline & Limousin & 80 & pedigree * \\
\hline & Holstein & 57 & $\mathrm{CDCB} *$ \\
\hline & Ayrshire & 185 & $\mathrm{CDCB} *$ \\
\hline & Brown Swiss & 72 & $\mathrm{CDCB}^{*}$ \\
\hline & Guernsey & 263 & $\mathrm{CDCB} *$ \\
\hline & Jersey & 79 & $\mathrm{CDCB} *$ \\
\hline Sheep & Black Welsh Mountain & 32 & pedigree * \\
\hline
\end{tabular}

When molecular markers have been used, particularly for sheep [22] and goats [23], the U.S. populations tend to be genetically diverse, with relatively high levels of observed heterozygosity. In addition, these studies suggest that when compared to breeds near the origin of domestication, little genetic diversity has been lost over the course of time [23].

Further work combining molecular (60K single nucleotide polymorphisms, SNP) and pedigree analysis in conjunction with Ward's method for clustering $[13,14]$ was performed using Duroc and Yorkshire pigs. The results to date show that $\sim 99 \%$ of the in situ alleles have been captured [25] in the collection. Encouragingly, these results suggest that comprehensive collections of genetic resources can be developed for future utilization.

\subsection{Future Work to Understand Genetic Diversity and Enhance Collections}

Setting aside collection completeness, which techniques or technologies are to be developed and used to strengthen germplasm collections? Experience to date suggests that there is a greater need to understand the interactions between environments and genetic resources through landscape genetics. Landscape genetics provides a basis for the evaluation of changes in the genetic structure of populations as impacted by environmental conditions [26]. The livestock sector has long known that interactions exist between genetics and the environment [27-29], and that these are important for determining animal productivity. However, little has been done to develop the magnitude of these interactions, or more specifically, to determine where the geographic intersection between differing performance levels caused by genetic and environmental interactions (GxE) are located. Such information is useful for livestock producers as combinations of breed, management systems, and environmental factors can be combined in attempts to evaluate and increase profitability [30]. The study of landscape genetics may provide a more comprehensive approach for evaluating GxE.

Initial steps: The gene bank collection has, to date, sampled breeds from a wide geographic distribution, as can be seen in the online database, Animal-GRIN. The collected samples can be useful in evaluating landscape genomics. Combining genetic/genomics and geographic differences can assist in evaluating genetic differences within and among populations. Pavia, et al. [31], using the beef cattle collection of the gene bank, demonstrated that regional climate (temperature, humidity, normalized 
difference vegetative index, and the computed temperature and humidity index) similarities and dissimilarities could project geographic ranges for different breed types (Bos taurus continental, Bos taurus British, and Bos indicus) within the U.S. By linking geographic information systems and individual animals within breed types from gene bank collections and identifying geographic regions where breeds could be successfully used, additional acquisitions to the gene back can be targeted.

We envision enhancing our understanding of genetic diversity in the context of landscape genetic analysis. Combined with the ability to combine phenotypic, genotypic, and environmental parameters like temperature, precipitation, and average thermal heat index, it will be possible to make any number of mapping overlays that the gene bank managers and/or researchers may require to evaluate breed or specific genotypic differences. For example, using SNP associated with an animal's ability to withstand environmental stressors, such as heat stress or altitude, can be important for maintaining within- and among-breed genetic diversity. By partitioning the U.S. into five geographic zones and assigning Hereford cattle to their respective regions, it was possible to determine how allelic frequencies for the identified SNP differed among regions [32]. This underscores the importance of knowing how subpopulations within a breed differ, and how those differences might be used to develop populations which are more resilient to environmental stress.

The utilization of landscape genetics, as described above, may prove to be of benefit to all breeds, but may have important consequences for breeds with less than 5000 animals. When these smaller populations are genotyped, that information can be combined with data from larger breeds. It may then be possible to perform fine scale analyses on the SNP of interest to quantify differences or similarities between small and large populations.

\subsection{Further Gene Bank Use}

As noted in Table 2, there are a variety of ways the gene bank can been used to advance different private or public sector objectives. To date, the owners of rare breeds have used the gene bank to reintroduce lost genetic variation for Dexter and Milking Shorthorn cattle breeds. In releasing samples to accomplish any given community's need, a new issue emerged: how to prevent overuse of the released genetics. Obviously, the cooperation and awareness of breed associations and breeders are needed to address potential over use. Recent work with the Livestock Conservancy involving the use of imported Large Black pig semen is like releasing germplasm from the gene bank. In that situation, contracts between the Livestock Conservancy and breeders using the semen set the stage for minimizing inbreeding and setting reasonable prices for progeny.

Because the effective population size tends to be low for many rare breeds, samples in the gene bank can be used to cross breeds and, in subsequent generations, backcross to the breed of interest until the desired percentage of breed composition is reached. In such a process it could be more advantageous to use breeds that are genetically similar. For example, Cotswold, Leicester Longwool, and Lincoln are all numerically-small breeds (Table 1), but their genetic distance from each other is relatively close, which suggests that the breeds might be mutually supportive [21]. In addition, Faria, et al. [24] showed that by combining all pig breeds in the gene bank, the current Ne would be 225 animals, suggesting that ample genetic diversity exists for any variety of purposes.

A major concern that rare breed groups express is a lack of genetic diversity that can result in high inbreeding levels. As a result, breeders often neglect selection which, in turn, increases the likelihood that genetic drift will randomly alter the breed [4]. Blackburn, et al. [6] demonstrated how breeders could effectively employ selection while minimizing inbreeding. In addition, the gene bank collection of germplasm can be used in support of selection efforts by reducing inbreeding levels of the in situ population.

\section{Conclusions}

Animal agriculture contributes over $60 \%$ of farm gate receipts in the U.S. The continued advancement of production efficiency will require the effective use of genetic variation. Therefore, 
animal agriculture needs greater engagement in terms of the conservation of animal genetic resources in general. Breeders of rare breeds find themselves in a problematic position, in that the lack of consistently measured information on phenotypic performance and genotypic evaluation suggests that the value of these populations is largely unknown. While it is often assumed that such breeds are an untapped genetic resource containing rare alleles not found elsewhere, definitive examples are largely missing from the literature. Until this question can be conclusively resolved, it will remain a challenge for rare breeds to increase in population size and in terms of their general viability among the livestock sector. That said, we know that the livestock sector is dynamic, and breed preferences change over time; the change in population size and industry preference for Hampshire and Berkshire pigs is such an example. However, until these outstanding issues have been sufficiently addressed, national gene banks may be the best hope for rare breed preservation.

Author Contributions: Data curation, C.S.W.; Writing—original draft, H.D.B.; Writing—review \& editing, B.K.

Funding: This research received no external funding.

Acknowledgments: Mention of trade names or commercial products in this publication is solely for the purpose of providing specific information and does not imply recommendation or endorsement by the U.S. Department of Agriculture. The USDA is an equal opportunity provider and employer.

Conflicts of Interest: The authors declare no conflicts of interest.

\section{References}

1. Food and Agriculture Organization. World Watch List for Domestic Animal Diversity, 1st ed.; Loftus, R., Scherf, B., Eds.; FAO: Rome, Italy, 1993.

2. Food and Agriculture Organization. The First Report on the State of the World's Animal Genetic Resources for Food and Agriculture; Rischkowsky, B., Pilling, D., Eds.; FAO: Rome, Italy, 2007.

3. FAO Commission on Genetic Resources for Food and Agriculture Assessments: Rome, Italy. 2015. Available online: http://www.fao.org/3/a-14787e/index.html (accessed on 30 November 2019).

4. Falconer, D.; Mackay, T. Introduction to Quantitative Genetics, 4th ed.; Longman Group Ltd.: Harlow, UK, 1996.

5. Eynard, S.E.; Windig, J.J.; Hulsegge, I.; Hiemstra, S.J.; Calus, M.P. The impact of using old germplasm on genetic merit and diversity-A cattle breed case study. J. Anim. Breed. Genet. 2018, 135, 311-322. [CrossRef] [PubMed]

6. The Role of Genetic Drift and Selection Intensity on Small Populations. Available online: http://www.wcgalp.org/system/files/proceedings/2018/role-genetic-drift-and-selection-intensitysmall-populations-sensitivity-and-genomic-analysis.pdf (accessed on 30 November 2019).

7. Maiwashe, N.A.; Blackburn, H.D. Genetic diversity in and conservation strategy considerations for Navajo Churro sheep. Anim. Sci. 2004, 82, 2900-2905. [CrossRef] [PubMed]

8. Welsh, C.S.; Stewart, T.S.; Schwab, C.; Blackburn, H.D. Pedigree analysis of 5 swine breeds in the United States and the implications for genetic conservation. J. Anim. Sci. 2010, 88, 1610-1618. [CrossRef] [PubMed]

9. Norton, R. Agricultural Development Policy: Concepts and Experiences; FAO: Rome, Italy, 2004.

10. Blackburn, H.D. Integrating policies for the management of animal genetic resources with demand for livestock products and environmental sustainability. Anim. Genet. Resour. Inf. 2007, 41, 53-64. [CrossRef]

11. Blackburn, H.D. Assuring genetic diversity with reproductive technologies: Development of national animal genetic resource programs. Reprod. Fertil. Dev. 2004, 16, 27-32. [CrossRef]

12. Blackburn, H.D. Genebank development for the conservation of livestock genetic resources in the United States of America. Livest. Sci. 2009, 120, 196-203. [CrossRef]

13. Blackburn, H.D. Biobanking genetic material for agricultural animal species. Annu. Rev. Anim. Biosci. 2018, 6, 69-82. [CrossRef]

14. Ouendeba, B.; Ejeta, G.; Hanna, W.; Kumar, A. Diversity among African pearl millet landrace populations. Crop Sci. 1995, 35, 919-924. [CrossRef]

15. Animal Genetic Resources. Available online: https://agrin.ars.usda.gov/database_collaboration_page_dev) (accessed on 18 November 2019).

16. Yue, X.-P.; Dechow, C.; Liu, W.-S. A limited number of Y chromosome lineages is present in North American Holsteins. J. Dairy Sci. 2015, 98, 2738-2745. [CrossRef] 
17. Dechow, C.D.; Liu, W.S.; Idun, J.S.; Maness, B. Short communication: Two dominant paternal lineages for North American Jersey artificial insemination sires. J. Dairy Sci. 2018, 101, 2281-2284. [CrossRef]

18. Food and Agriculture Organization. Cryoconservation of Animal Genetic Resources; FAO Animal Production and Health Guidelines No. 12; FAO: Rome, Italy, 2012.

19. Leroy, G.; Danchin-Burge, C.; Verrier, E. Impact of the use of cryobank samples in a selected cattle breed: A simulation study. Genet. Sel. Evol. 2011, 43, 36. [CrossRef]

20. Dechow, C.D.; Liu, W.S.; Specht, L.W.; Blackburn, H. Reconstitution and modernization of lost Holstein male lineages using samples from a gene bank. J. Dairy Sci.. under review.

21. Blackburn, H.D.; Paiva, S.R.; Wildeus, S.; Getz, W.; Stobart, R.; Bixby, D.; Purdy, P.H.; Welsh, C.S.; Spiller, S.F.; Brown, M.A. Genetic Structure and Diversity among U.S. sheep breeds: Identification of the major gene pools. J. Anim. Sci. 2011, 89, 2336-2348. [CrossRef] [PubMed]

22. Blackburn, H.D.; Toishibekov, Y.; Toishibekov, M.; Welsh, C.S.; Spiller, S.F.; Brown, M.; Paiva, S.R. Genetic diversity of Ovis aries populations near domestication centers and in the New World. Genetica 2011, 139, 1169-1178. [CrossRef] [PubMed]

23. Do Prado, P.T.; Faria, D.A.; McManus, C.; Lanari, M.R.; Esquivel, L.C.; Cascante, M.I.; Alfaro, E.J.; Mendez, A.; Faco, O.; de Moraes, S.K.; et al. New world goat populations are a genetically diverse reservoir for future use. Sci. Rep. 2019, 9, 1476. [CrossRef]

24. Faria, D.A.; Wilson, C.; Paiva, S.; Blackburn, H.D. Assessing Sus scrofa diversity among continental United States, and Pacific islands populations using molecular markers from a gene banks collection. Sci. Rep. 2019, 9, 3173. [CrossRef]

25. Wilson, C.S.; Rohrer, G.A.; Newcom, D.W.; Blackburn, H.D. 217 Capturing genetic diversity—an assessment of the nation's gene bank in securing Duroc pigs. J. Anim. Sci. 2019, 97, 46.

26. Manel, S.; Holderegger, R. Ten years of landscape genetics. Trends Ecol. Evol. 2013, 28, 10. [CrossRef]

27. Cartwright, T.C. Responses of beef cattle to high ambient temperatures. J. Anim. Sci. 1955, 14, 350-362. [CrossRef]

28. Kroger, M.; Burns, W.; Pahnish, O.; Butts, W. Genotype by environment interactions in Hereford cattle: I. Reproductive Traits. J. Anim. Sci. 1979, 49, 396-402. [CrossRef]

29. Bohmanova, J.; Misztal, I.; Tsuruta, S.; Norman, H.; Lawlor, T. Genotype by environment interaction due to heat stress. J. Dairy Sci. 2008, 91, 840-846. [CrossRef] [PubMed]

30. Blackburn, H.D.; Pittroff, W. Biologically based coefficients for partitioning lamb and wool production costs. J. Anim. Sci. 1999, 77, 1353-1363. [CrossRef] [PubMed]

31. Paiva, S.R.; Hermuche, P.; Costa Junior, J.; McManus, C.; Fontes Guimaraes, R.; Carvalho Junior, O.; Wislon, C.; Krehbiel, B.; Blackburn, H.B.; Auckland, N.Z. Gene bank collection strategies based upon geographic and environmental indicators. World Cong. Gen. Appl. Livstk Prod. 2017, 11, 747.

32. Blackburn, H.D.; Krehbiel, B.; Ericsson, S.A.; Wilson, C.S.; Caetano, A.R.; Paiva, S.R. A fine structure genetic analysis evaluating ecoregional adaptability of a Bos taurus breed (Hereford). PLoS ONE 2017, 12, e0176474. [CrossRef] [PubMed]

(C) 2019 by the authors. Licensee MDPI, Basel, Switzerland. This article is an open access article distributed under the terms and conditions of the Creative Commons Attribution (CC BY) license (http://creativecommons.org/licenses/by/4.0/). 